SILENCE and DEMOCRACY 



\section{SILENCE and DEMOCRACY}

Athenian Politics in Thucydides' History

JOHN ZUMBRUNNEN

The Pennsylvania State University Press

University Park, Pennsylvania 
Library of Congress

Cataloging-in-Publication Data

Zumbrunnen, John.

Silence and democracy : Athenian politics in Thucydides' history / John Zumbrunnen.

p. $\mathrm{cm}$.

Includes bibliographical references and index. ISB N 978-0-27I-03357-0 (cloth : alk. paper)

I. Democracy-Greece-Athens-History-To 1500.

2. Political participation-Greece-Athens-History-To I500.

3. Thucydides. History of the Peloponnesian War.

4. Athens (Greece)-Politics and government.

$$
\text { I. Title. }
$$

$$
\begin{gathered}
\mathrm{JC}_{75} \mathrm{D}_{3} 6 \mathrm{Z} 862008 \\
320.938^{\prime} 5-\mathrm{dc} 22 \\
2007043310
\end{gathered}
$$

Copyright (C) 2008

The Pennsylvania State University

All rights reserved

Printed in the United States of America

Published by The Pennsylvania State University Press,

University Park, PA I6802-1003

The Pennsylvania State University Press

is a member of the

Association of American University Presses.

It is the policy of

The Pennsylvania State University Press to use

acid-free paper. This book is printed on Natures Natural, containing $50 \%$ post-consumer waste, and meets the minimum requirements of American National Standard for Information Sciences-Permanence of Paper for Printed Library Material, ANSI Z39.48-I992. 